\title{
ANALISIS BIAYA VOLUME LABA SEBAGAI ALAT PERENCANAAN LABA PADA CV WARINGIN PUTIH SEMARANG
}

\author{
Novan Yudi Cahyadi, Sulistiyo \\ Jurusan Akuntansi, Politeknik Negeri Semarang \\ Jl. Prof. H. Sudarto, S.H., Tembalang, Semarang 50275
}

\begin{abstract}
This final project discusses how profit planning at $C V$ Waringin Putih Semarang by applying the cost volume profit analysis. The purpose of this final project is to calculate the contribusion margin, break even point, profit planning in 2017, margin of safety, degree of operating leverage, and shut down point, and also to examine the asumpsions that affect profit at $C V$ Waringin Putih Semarang with sensitivity analysis.

The method of collecting data used in this final project is interviews, and documentation. The data used are secondary data obtained from CV Waringin Putih Semarang includes sales data, cost data, and general overview of the company. The writing of this final project used description method and exposition method. Description method used to describe the general overview of the company, while exposition method used to calculate the approaches that will be used to describe the cost volume profit analysis.

Based on the cost volume profit analysis has been done, obtained the weighted a verage contribution margin of Rp20.638,73 per $\mathrm{m}^{2}$. Sales to break even point as much as $24.024 \mathrm{~m}^{2}$. Sales to reach the profit target increased by 17,21\%, or as much as $66.026 \mathrm{~m}^{2}$. Margin of safety is $63,62 \%$ and degree of operating leverage is about 1,74, and also sales to shut down point as much as $20.655 \mathrm{~m}^{2}$. Key Words: Cost Volume Profit Analysis, Profit Planning
\end{abstract}

Abstrak: Tugas akhir ini membahas bagaimana perencanaan laba pada CV Waringin Putih Semarang dengan menerapkan analisis volume biaya. Tujuan dari tugas akhir ini adalah menghitung margin kontribusinya, break even point, perencanaan laba pada tahun 2017 , margin of safety, tingkat operating leverage, dan shut down point, dan juga untuk menguji asteredions yang mempengaruhi keuntungan pada CV Waringin Putih Semarang. dengan analisis sensitivitas.

Metode pengumpulan data yang digunakan dalam tugas akhir ini adalah wawancara dan dokumentasi. Data yang digunakan adalah data sekunder yang diperoleh dari CV Waringin Putih Semarang meliputi data penjualan, data biaya, dan gambaran umum perusahaan. Penulisan tugas akhir ini menggunakan metode deskripsi dan metode eksposisi. Metode deskripsi yang digunakan untuk menggambarkan gambaran umum perusahaan, sedangkan metode exposition digunakan untuk menghitung pendekatan yang akan digunakan untuk menggambarkan analisis volume biaya.

Berdasarkan analisis biaya perolehan volume telah dilakukan, diperoleh marjin kontribusi rata-rata tertimbang sebesar Rp20.638,73 per m2. Penjualan mencapai titik impas sebanyak $24.024 \mathrm{~m} 2$. Penjualan untuk mencapai target laba meningkat sebesar 17,21\% atau sebanyak 66,026 m2. Marjin keselamatan adalah $63,62 \%$ dan tingkat leverage operasi sekitar 1,74 , dan juga penjualan untuk shut down point sebanyak $20.655 \mathrm{~m} 2$.

Kata Kunci: Analisis Laba Volume Biaya, Perencanaan Laba 


\section{PENDAHULUAN}

\section{Latar Belakang Masalah}

Manajemen dalam perusahaan memiliki dua fungsi pokok, yaitu perencanaan dan pengendalian aktivitas perusahaan. Fungsi perencanaan merupakan langkah awal bagi manajemen dalam mengelola perusahaan sebelum melakukan pengendalian atas segala aktivitas yang sebelumnya telah direncanakan. Dalam membuat perencanaan, manajemen memerlukan cara yang tepat agar diperoleh perencanaan yang matang dalam memilih berbagai alternatif tindakan yang akan dijalankan dimasa mendatang.

Keberhasilan manajemen dalam menjalankan fungsi pokok dan tanggung jawab seringkali dilihat dari jumlah laba yang diperoleh perusahaan. Setiap perusahaan memiliki tujuan untuk memperoleh laba semaksimal mungkin. Jumlah laba yang besar dinilai dapat membuat perusahaan lebih mudah untuk terus menjalankan usahanya. Untuk itu, penting bagi manajemen membuat perencanaan laba, karena dalam perencanaan laba manajemen dapat memilih berbagai macam alternatif dan kebijakan yang berguna untuk meningkatkan laba dimasa yang akan datang sesuai dengan jumlah laba yang diharapkan.

Laba yang diperoleh perusahaan dipengaruhi oleh tiga faktor, yaitu harga jual, volume penjualan, dan biaya yang dikeluarkan. Ketiga faktor tersebut memiliki keterkaitan satu sama lain. Manajemen dalam melakukan perencanaan laba harus benar-benar memahami hubungan antara ketiga faktor tersebut agar didapat perhitungan laba yang akurat.

Analisis Biaya Volume Laba (Cost Volume Profit Analysis) merupakan alat yang sangat berguna dalam perencanaan dan pembuatan keputusan, khususnya dalam perencanaan laba. Analisis Biaya Volume Laba memberikan pemahaman tentang hubungan antara harga jual produk, volume penjualan, dan biaya yang dikeluarkan perusahaan. Penerapan Analisis Biaya Volume Laba memiliki banyak manfaat bagi manajemen dalam mengambil keputusan terbaik. Dengan menerapkan Analisis Biaya Volume Laba dapat diketahui dampak perubahan volume terhadap perubahan biaya, pendapatan, dan laba.

Analisis Biaya Volume Laba menyediakan data mengenai margin kontribusi produk, titik impas (Break Even Point), margin pengaman (Margin Of Safety), titik penutupan perusahaan (Shut Down Point), dan tingkat Leverage Operasi (Degree Of Operating Leverage), serta memungkinkan manajemen untuk melakukan analisis sensitivitas untuk menguji dampak perubahan harga jual dan biaya terhadap laba. Selain itu, bagi perusahaan yang menghasilkan produk lebih dari satu jenis produk, Analisis Biaya Volume Laba juga dapat digunakan untuk menentukan bauran produk yang terbaik agar dapat mencapai laba yang diharapkan.

Industri pembuatan paving merupakan salah satu industri yang membutuhkan Analisis Biaya Volume Laba dalam menjalankan usahanya. Ditengah ramainya pembangunan kota yang kian meningkat, kompetitor industri sejenis yang semakin banyak dan modern membuat manajemen dihadapkan dengan berbagai situasi sulit dalam menyediakan produk paving yang berkualitas dengan harga yang bersaing. Disamping itu, dengan Analisis Biaya Volume Laba memungkinkan manajemen untuk melakukan pengendalian terhadap biayabiaya yang dikeluarkan, menentukan jumlah laba yang diinginkan, dan merencanakan jumlah penjualan yang harus dicapai untuk memperoleh laba yang direncanakan.

CV Waringin Putih Semarang merupakan industri yang bergerak dibidang pembuatan berbagai macam jenis paving dan batako. Setiap tahunnya CV Waringin Putih Semarang dapat memproduksi dan menjual puluhan ribu meter persegi paving dan batako. Industri yang telah berdiri sejak tahun 1976 ini memiliki area pemasaran yang mencakup seluruh kota Semarang dan sekitarnya. Ditengah ramainya pembangunan kota Semarang dan daerah di sekitarnya, membuat CV Waringin Putih Semarang ingin memaksimalkan potensi yang ada untuk bisa memaksimalkan tingkat 
penjualan dan memperoleh laba yang optimal. Selama ini dalam menjalankan usaha CV Waringin Putih Semarang belum pernah membuat perencanaan laba sehingga manajemen tidak bisa secara maksimal mengendalikan tingkat penjualan dan biaya yang dikeluarkan.

\section{Perumusan Masalah}

CV Waringin Putih Semarang adalah industri yang memproduksi dan menjual berbagai macam jenis Paving dan Batako diantaranya Paving Holland, Paving Unipave, Paving Hexagonal, Grass Block, Topi Uskup, dan Batako. Berdasarkan latar belakang diatas diketahui CV Waringin Putih Semarang belum pernah membuat perencanaan laba, sehingga manajemen membutuhkan informasi terkait faktor-faktor yang mempengaruhi laba. Analisis Biaya Volume Laba menyajikan informasi yang dibutuhkan oleh manajemen dalam perencanaan laba. Dalam membuat perencanaan laba tahun 2017 digunakan data CV Waringin Putih Semarang tahun 2016 sebagai acuan. Berdasarkan uraian diatas dapat disusun rumusan masalah sebagai berikut:

a. Berapa besar Margin Kontribusi dan Rasio Margin Kontribusi produk pada CV Waringin Putih Semarang?

b. Berapa jumlah penjualan yang harus dicapai CV Waringin Putih Semarang untuk mencapai titik impas (Break Even Point)?

c. Berapa jumlah penjualan dan persentase kenaikan penjualan yang harus dicapai CV Waringin Putih Semarang pada tahun 2017 jika laba ditargetkan meningkat sebesar 30\% dari tahun 2016?

d. Berapa besar margin pengaman (Margin Of Safety) bagi CV Waringin Putih Semarang agar tidak mengalami kerugian?

e. Berapa besar titik penutupan usaha (Shut Down Point) dan tingkat Operating Leverage pada CV Waringin Putih Semarang?

f. Bagaimana menguji dampak dari perubahan asumsi-asumsi perusahaan menggunakan analisis sensitivitas pada CV Waringin Putih Semarang?
TINJAUAN PUSTAKA

Pengertian Analisis Biaya Volume Laba

Analisis biaya volume laba (cost volume profit analysis - CVP analysis) merupakan suatu alat yang sangat berguna untuk perencanaan dan pengambilan keputusan (Hansen dan Mowen, 2009). Mulyadi (2015) menyatakan bahwa analisis hubungan biaya-volume-laba (cost-volume-profit analysis) merupakan teknik untuk menghitung dampak perubahan harga jual, volume penjualan dan biaya terhadap laba, untuk membantu manajemen dalam perencanaan laba jangka pendek. Garrison et al. (2013) mendefinisikan analisis biaya-volumelaba (BVL) sebagai alat bantu yang sangat berguna bagi manajer untuk memahami hubungan antara biaya, volume, dan laba. Analisis BVL berfokus pada pengaruh dari kelima faktor berikut terhadap laba:

a. Harga produk

b. Volume penjualan

c. Biaya variabel per unit

d. Total biaya tetap

e. Bauran produk yang dijual

Tujuan Analisis Biaya Volume Laba Salman dan Farid (2016) menjabarkan tujuan implementasi analisis biaya volume laba ini meliputi:

a. Dalam rangka meramal laba secara akurat, faktor yang penting adalah mengetahui hubungan antara laba dan biaya pada satu sisi dan volume pada sisi yang lain.

b. Analisis biaya-volume-penjualan bermanfaat dalam menyusun flexible budget yang mengindikasikan biaya pada banyak level aktivitas.

c. Analisis CVP membantu evaluasi kinerja untuk tujuan pengendalian. Hal ini bisa dilakukan dengan melakukan review laba dan biaya serta perubahan volume.

d. Analisis hubungan CVP mendukung penetapan kebijakan harga yang sesuai dengan kondisi lingkungan.

e. Tarif overhead pabrik yang ditentukan dimuka berhubungan dengan volume produksi, maka mempelajari hubungan biaya dan volume adalah penting untuk mengetahui jumlah biaya overhead 
yang akan dibebankan ke biaya produk pada berbagai tingkat operasi.

\section{Asumsi Analisis Biaya Volume Laba}

Simamora (2012) mengemukakan asumsi-asumsi yang perlu diperhatikan dalam penerapan analisis biaya volume laba agar diperoleh hasil analisis yang tepat dan akurat. Asumsi tersebut adalah sebagai berikut:

a. Semua biaya diklasifikasikan sebagai biaya variabel ataupun biaya tetap. Biaya lainnya, seperti biaya campuran, dianggap dapat dipilah-pilah menjadi unsur biaya variabel dan unsur biaya tetap. Jumlah biaya tetap sifatnya konstan pada saat aktivitas berubah, dan biaya variabel per unit tidak berganti ketika aktivitas berubah. Efisiensi dan produktivitas proses produksi serta tenaga kerja dianggap konstan pula.

b. Fungsi jumlah biaya adalah linier dalam kisaran relevan. Asumsi ini sahih dalam kisaran relevan kegiatan usaha normal.

c. Fungsi jumlah pendapatan adalah linier dalam kisaran relevan. Harga jual per unit dianggap konstan dalam kisaran volume produksi. Hal ini menyiratkan pasar yang murni kompetitif untuk produk atau jasa akhir. Jumlah pendapatan berubah sebanding dengan perubahan volume penjualan unit produk. Harga jual rata-rata per unit produk adalah konstan.

d. Analisisnya untuk sebuah produk, atau bauran penjualan bermacammacam produk adalah konstan dalam kisaran relevan. Apabila produk mempunyai harga jual dan biaya yang berbeda-beda, perubahan bauran penjualan akan mempengaruhi hasil analisis biayavolume-laba.

e. Hanya ada satu pemicu biaya: volume unit produk atau nilai penjualan.

f. Dalam perusahaan pabrikasi, tingkat persediaan pada awal dan akhir periode adalah sama. Hal ini menunjukkan bahwa jumlah unit yang diproduksi selama periode berjalan sama dengan unit yang dijual.

\section{Pengertian Biaya}

Biaya (cost) adalah pengorbanan sumber ekonomi untuk memperoleh barang atau jasa yang diharapkan memberi manfaat sekarang atau masa yang akan datang (Siregar et al., 2013). Salman dan Farid (2016) menyatakan bahwa biaya adalah kas atau nilai ekuivalen kas yang dikorbankan untuk mendapatkan barang atau jasa yang diharapkan memberi manfaat saat ini atau dimasa yang akan datang bagi organisasi.

Berdasarkan definisi diatas, dapat disimpulkan bahwa biaya adalah pengorbanan sumber ekonomi, yang diukur dalam satuan uang untuk memperoleh barang atau jasa yang diharapkan memberi manfaat saat ini maupun dimasa yang akan datang.

Perilaku Biaya dan Klasifikasinya

Perilaku biaya (cost behavior) berarti bagaimana suatu biaya akan bereaksi atau merespons perubahan tingkat aktivitas usaha (Simamora 2012). Siregar et al. (2013) menyatakan bahwa perilaku biaya (cost behavior) adalah pola yang menggambarkan bagaimana jumlah biaya bervariasi atas perubahan aktivitas bisnis. Salman dan Farid (2016) menyatakan bahwa perilaku biaya adalah cara biaya berubah dalam hubungannya dengan perubahan penggunaan aktivitas. Atau dengan kata lain, perilaku biaya adalah istilah untuk menggambarkan apakah biaya berubah seiring dengan perubahan output.

Perilaku biaya terhadap perubahan aktivitas perusahaan, biaya dapat dibagi menjadi tiga golongan yaitu: biaya variabel, biaya tetap, dan biaya campuran (biaya semivariabel atau biaya semitetap).

\section{a. Biaya Variabel}

Biaya variabel (variable cost) adalah biaya yang jumlah keseluruhannya bervariasi secara proporsional terhadap perubahan keluaran (Salman dan Farid 2016). Siregar et al. (2013) mendefinisikan biaya variabel (variable cost), yaitu biaya yang jumlah totalnya berubah sebanding dengan perubahan aktivitas dan volume produksi, 
sementara jumlah per unitnya tidak berubah.

b. Biaya Tetap

Biaya tetap merupakan biaya yang jumlah totalnya tidak berubah dengan adanya perubahan volume kegiatan dalam kisar (range) perubahan volume kegiatan tertentu (Mulyadi 2015). Simamora (2012) menyatakan bahwa biaya tetap (fixed cost) ialah biaya yang jumlahnya tidak berubah (konstan), terlepas dari perubahan tingkat aktivitas dalam kisar relevan tertentu. Jumlah biaya tetap yang tidak terpengaruh oleh perubahan tingkat aktivitas perusahaan menyebabkan biaya tetap per unit produk menjadi berubah pada tingkat aktivitas yang berbedabeda.

c. Biaya Campuran

Biaya campuran (mixed cost) adalah biaya yang mengandung unsurunsur biaya variabel dan tetap. Biaya campuran disebut juga biaya semivariabel (Simamora, 2012). Siregar et al. (2013) menyatakan bahwa biaya campuran (mixed cost) adalah biaya yang memiliki karakteristik biaya variabel sekaligus biaya tetap. Sebagian dari biaya campuran berubah mengikuti perubahan aktivitas secara proporsional. Sementara, sebagian yang lain tidak berubah meski tingkat aktivitasnya berubah.

\section{Pemisahan Biaya Campuran}

Biaya campuran mengandung unsur biaya variabel sekaligus biaya tetap. Mengacu pada salah satu asumsi analisis biaya volume laba, yakni semua biaya diklasifikasikan sebagai biaya variabel ataupun biaya tetap, diperlukan pemisahan unsur biaya variabel dan biaya tetap yang terdapat pada biaya campuran dalam penerapan analisis biaya volume laba, agar diperoleh hasil analisis dan estimasi yang tepat dan akurat. Menurut Siregar et al. (2013) ada tiga pendekatan yang lazim digunakan dalam memisahkan biaya variabel dan biaya tetap dalam biaya campuran. Ketiga metode tersebut adalah: a. Metode grafik (scatterplot method)

b. Metode titik tertinggi dan terendah (highest dan lowest point method)

c. Metode regresi kuadrat terkecil (least squares regression method)

\section{Pengertian Laba}

Laba merupakan tujuan utama sekaligus tolak ukur keberhasilan manajemen perusahaan. Dengan memperoleh laba, manajemen dapat terus mempertahankan dan mengembangkan kegiatan usaha. Salman dan Farid (2016) menyatakan bahwa selisih antara pendapatan dan biaya diistilahkan dengan laba (profit) atau rugi (loss). Laba operasi (operating income) hanya mencakup pendapatan dan beban dari operasional normal perusahaan. Laba bersih (net income) adalah laba operasi dikurangi pajak penghasilan (Hansen dan Mowen, 2009).

\section{Perencanaan Laba}

Perencanaan merupakan langkah awal bagi perusahaan dalam menjalankan aktivitas usahanya. Perencanaan harus dibuat sebaik mungkin karena berguna sebagai acuan dan alat pengendali bagi manajemen dalam menjalankan aktivitas usahanya di masa yang akan datang. Perencanaan laba pada dasarnya merupakan perencanaan yang harus dilakukan manajemen dalam rangka mencapai tujuan, yakni mencapai laba yang diharapkan. Tahap-tahap yang dilakukan oleh organisasi bisnis untuk mencapai tingkat laba yang diharapkan sebuah proses yang disebut perencanaan laba (Garrison et al., 2013).

Margin Kontribusi dan Rasio Margin Kontribusi

Margin kontribusi (contribution margin) merupakan selisih antara hasil penjualan dan seluruh komponen beban variabel (produksi, administrasi, dan penjualan) (Sodikin, 2015). Jumlah tersebut dapat digunakan untuk menutup biaya tetap dan memperoleh laba dalam periode tersebut. Apabila margin kontribusi lebih besar dari biaya tetap, maka perusahaan akan memperoleh laba. Sebaliknya, jika margin kontribusi lebih kecil dari biaya tetap, maka perusahaan akan mengalami kerugian. Namun, apabila margin kontribusi dan biaya tetap sama besar, kondisi inilah yang disebut 
titik impas perusahaan atau break even point.

Rasio margin kontribusi merupakan perbandingan antara margin kontribusi dan penjualan. Rasio ini menunjukkan persentase tiap satu rupiah penjualan yang dapat digunakan untuk menutup beban tetap dan kemudian laba (Sodikin, 2015). Rasio margin kontribusi sangat bermanfaat bagi manajemen untuk mengetahui perubahan margin kontribusi sebagai akibat perubahan setiap rupiah penjualan.

Samryn (2012) mengungkapkan margin kontribusi dan rasio margin kontribusi dapat ditentukan dengan formulasi sebagai berikut:

a. Margin Kontribusi

$=$ Penjualan - Biaya Variabel

b. Rasio Margin Kontribusi

$$
=\frac{\text { Margin Kontribusi }}{\text { Penjualan }} \%
$$

\section{Titik Impas (Break Even Point)}

Titik impas (break-even point) adalah keadaan yang menunjukkan bahwa jumlah pendapatan yang diterima perusahaan (pendapatan total) sama dengan jumlah biaya yang dikeluarkan perusahaan (biaya total) (Siregar et al., 2013). Mulyadi (2015) mendefinisikan titik impas (break-even) sebagai keadaan suatu usaha yang tidak memperoleh laba dan tidak menderita rugi. Dengan kata lain, suatu usaha dikatakan impas jika jumlah pendapatan (revenues) sama dengan biaya, atau apabila laba kontribusi hanya dapat digunakan untuk menutup biaya tetap saja.

Titik impas dapat ditentukan secara matematis atau secara grafis, dan dapat pula dinyatakan dalam unit penjualan maupun rupiah penjualan. Terdapat tiga pendekatan dalam menentukan titik impas (break even point), diantaranya:

a. Pendekatan laba operasi (metode persamaan)

Ancangan matematis dengan menggunakan pendekatan laba operasi adalah berdasarkan pada laporan laba rugi dengan format margin kontribusi. Dengan menggunakan format margin kontribusi, laporan laba rugi dapat mempermudah pengorganisasian biaya-biaya perusahaan dalam kategori biaya tetap dan variabel. Formulasi penentuan titik impas dengan pendekatan laba rugi menurut Hansen dan Mowen (2009) adalah sebagai berikut:

1) Laba Operasi = Penjualan Biaya variabel - Biaya tetap, atau

2) Laba Operasi $=($ Harga $\mathrm{x}$ Jumlah unit terjual) - (Biaya variabel per unit x Jumlah unit terjual) - Biaya Tetap

b. Pendekatan margin kontribusi Metode kontribusi unit (unit contribution method) sebenarnya merupakan variasi metode persamaan. Metode ini terfokus pada gagasan bahwa setiap unit atau satuan produk yang terjual memberikan sebuah jumlah margin kontribusi tertentu yang akan menutup biaya tetap (Simamora, 2012). Penentuan titik impas dengan pendekatan margin kontribusi dapat menggunakan formulasi sebagai berikut (Siregar et al., 2013):

1) Unit Impas

$$
=\frac{\text { Biaya Tetap Total }}{\text { Margin Kontribusi per unit }}
$$

2) Penjualan Impas (Rp)

$$
=\frac{\text { Biaya Tetap Total }}{\text { Rasio Margin Kontribusi }}
$$

c. Pendekatan grafis

Perhitungan impas dapat dilakukan juga dengan menentukan titik pertemuan antara garis pendapatan penjualan dengan garis biaya dalam suatu grafik. Titik pertemuan antara garis pendapatan penjualan dengan garis biaya merupakan titik impas (Mulyadi, 2015). Berikut ilustrasi grafik break even point menurut Mulyadi (2015): 


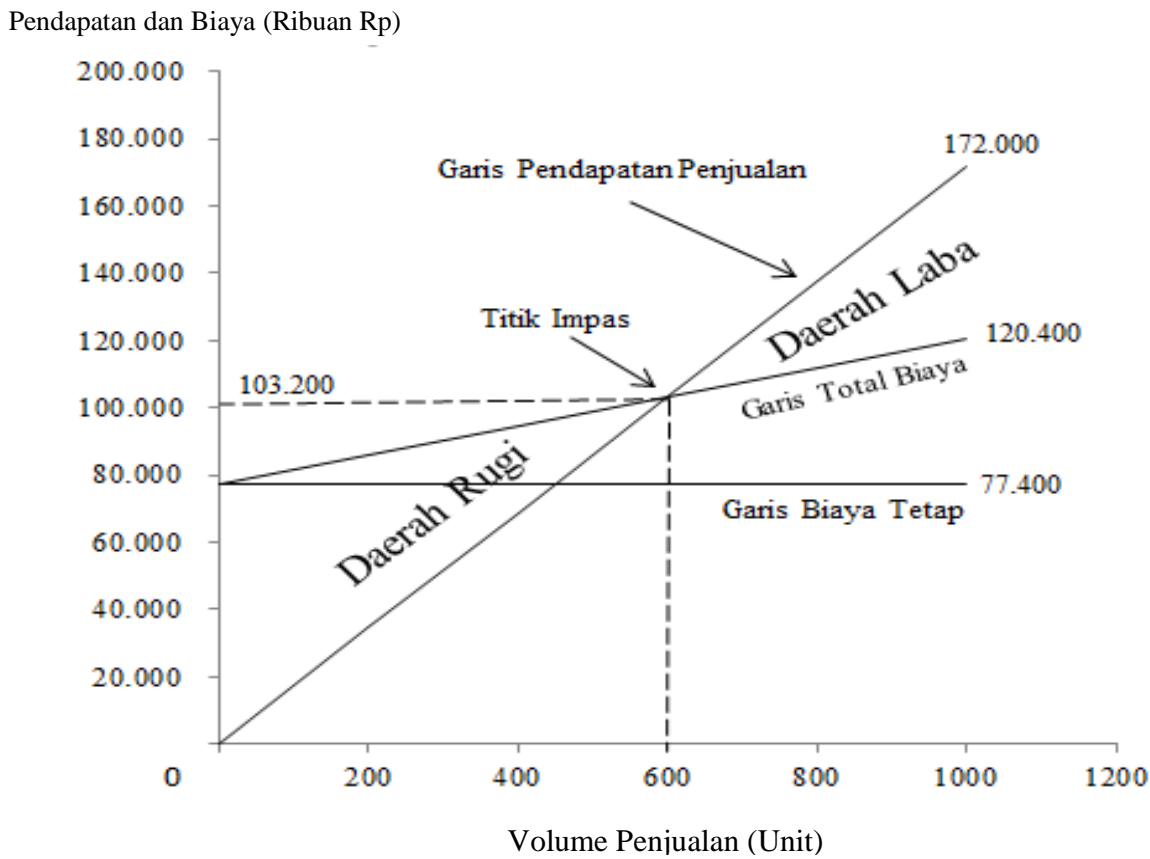

Gambar 1. Grafik Titik Impas (Break Even Point)

\section{Margin Pengaman (Margin of Safety)}

Margin pengaman atau margin of safety memberikan informasi tentang sampai sejauh mana volume penjualan boleh turun dari penjualan yang telah dianggarkan, namun tidak sampai merugikan perusahaan. Selisih antara volume penjualan yang dianggarkan dengan volume penjualan impas merupakan angka margin of safety (Mulyadi, 2015). Salman dan Farid (2016) menyatakan bahwa margin pengaman adalah kelebihan penjualan yang dianggarkan atas volume penjualan impas.

Margin pengaman dapat dinyatakan dalam unit penjualan, rupiah penjualan dan, persentase terhadap penjualan yang dianggarkan. Berikut merupakan formulasi dalam menentukan margin pengaman menurut Simamora (2012):

a. Margin Pengaman = Penjualan dianggarkan - Penjualan impas

b. Persertase margin pengaman = Margin pengaman

Pengungkit Operasi (Operating Leverage) Pengungkit operasi (operating leverage) merupakan penggunaan biaya tetap untuk menciptakan perubahan persentase laba yang lebih tinggi ketika aktivitas penjualan berubah (Hansen dan Mowen, 2009). Disamping itu, Simamora (2012) menyatakan bahwa tingkat pengungkit operasi (degree of operating leverage) ialah sebuah ukuran, pada tingkat penjualan tertentu, seberapa besar persentase perubahan volume penjualan akan mempengaruhi laba usaha. Tingkat pengungkit operasi dapat dihitung dengan menggunakan formula (Garrison et al., 2013):

Tingkat Leverage Operasi

$$
=\frac{\text { Margin Kontribusi }}{\begin{array}{c}
\text { Laba Neto } \\
\text { pendekatan tingkat }
\end{array}}
$$
operating leverage tersebut, manajemen dapat membuat proyeksi peningkatan laba dengan formula sebagai berikut:

Persentase perubahan laba neto operasi $=$ Tingkat leverage operasi $\mathrm{x}$ Persentase perubahan penjualan

\section{Titik Penutupan Usaha (Shut Down Point)}

Titik penutupan usaha merupakan suatu keadaan yang menunjukkan contribution margin perusahaan hanya bisa digunakan untuk menutup biaya tetap yang bersifat tunai (Kusuma et al., 
2013).

Perusahaan

dapat

dipertimbangkan untuk ditutup apabila hasil penjualan tidak lagi dapat menutupi biaya tetap tunai. Hal itu disebabkan kelanjutan usaha harus dibiayai dari sumber lain yang berasal dari luar perusahaan. Sumber dana seperti ini umumnya menimbulkan tambahan biaya tunai. Tingkat penjualan shut down point baik dalam unit maupun rupiah dapat ditentukan dengan formula sebagai berikut:

Shut Down Point (Unit)

$$
=\frac{\text { Biaya tetap tunai }}{\text { Margin kontribusi per unit }}
$$

Shut Down Point (Rupiah)

\section{Bauran Penjualan (Sales Mix)}

$$
=\frac{\text { Biaya tetap tunai }}{\text { Rasio margin kontribusi }}
$$

Pada umumnya perusahaan menjual berbagai macam jenis produk dengan berbagai tingkat harga jual. Jenis produk yang berbeda memungkinkan konsumsi biaya variabel yang berbeda pula antara satu produk dengan produk lain. Sehingga, setiap jenis produk memiliki margin kontribusi yang berbeda.

Produk dengan margin kontribusi lebih tinggi akan memberikan proporsi lebih besar dalam menutup biaya tetap. Sebaliknya, produk dengan margin kontribusi lebih rendah akan memberikan proporsi yang lebih kecil. Oleh karena itu, volume penjualan yang diperlukan untuk mencapai titik impas maupun target laba bagi perusahaan yang menjual lebih dari satu jenis produk sangatlah tergantung pada bauran penjualan.

Bauran penjualan (sales mix) merupakan komposisi relatif penjualan produk perusahaan. Penjualan dihitung dengan menyatakan penjualan tiap produk sebagai persentase dari total penjualan (Samryn, 2012). Garrison et al. (2013) menyatakan istilah bauran penjualan (sales mix) mengacu pada proporsi relatif di mana produk perusahaan dijual.

\section{Analisis Target Laba}

Penentuan target laba merupakan hal yang penting dalam perencanaan perusahaan. Laba merupakan tujuan utama sekaligus tolak ukur keberhasilan manajemen perusahaan. Analisis biaya volume laba dapat diterapkan dalam penentuan target laba. Analisis biaya volume laba dapat menunjukkan volume produk yang harus dijual dan nilai penjualan yang harus dicapai dengan memperhitungkan biaya yang dikorbankan untuk memperoleh tingkat laba yang diinginkan.

Analisis target laba (target profit analysis) adalah mengestimasi volume penjualan yang diperlukan untuk mencapai target laba yang diinginkan (Garrison et al., 2013). Simamora (2012) menyatakan bahwa besarnya keuntungan yang diharapkan oleh pemodal sering disebut laba sasaran (target profit). Untuk menghitung jumlah penjualan dan unit penjualan yang harus dicapai dalam memperoleh laba yang diinginkan dapat menggunakan metode persamaan dan metode margin kontribusi sebagai berikut:

a. Metode Persamaan

Metode persamaan laba digunakan untuk mengetahui nilai penjualan yang harus dicapai untuk mencapai target laba. Menurut Garisson et al. (2013) persamaan tersebut adalah sebagai berikut:

Laba $=$ Rasio margin kontribusi $\mathrm{x}$ Penjualan - Beban tetap

Untuk mengetahui unit penjualan yang harus dicapai untuk mencapai target laba adalah sebagai berikut:

Laba $=$ Margin kontribusi per unit $\mathrm{x}$ $\mathrm{Q}$ - Beban tetap.

b. Metode Margin Kontribusi

Metode margin kontribusi merupakan versi pintas dari metode persamaan. Untuk menghitung penjualan yang harus dicapai dalam mencapai target laba menurut Garrison et al. (2013) adalah dengan cara sebagai berikut:

Nilai penjualan

$=\frac{\text { Target laba }+ \text { Beban tetap }}{\text { Rasio margin kontribusi }}$

Untuk mengetahui unit penjualan yang harus dicapai untuk mencapai target laba adalah sebagai berikut:

Unit penjualan

$=\frac{\text { Target laba }+ \text { Beban tetap }}{\text { Margin kontribusi per unit }}$

\section{Analisis Sensitivitas}

Analisis faktor-faktor yang dapat mempengaruhi laba perusahaan dikenal dengan analisis sensitivitas. Analisis 
sensitivitas (sensitivity analysis) adalah teknik "bagaimana-jika" yang menguji dampak dari perubahan asumsi-asumsi yang mendasarinya terhadap suatu jawaban (Hansen dan Mowen, 2009). Melakukan analisis sensivitas cukup mudah, yakni dengan menggunakan data harga jual, biaya variabel, biaya tetap, dan bauran penjualan. Kemudian dengan data tersebut dapat diperhitungkan titik impas dan laba yang diharapkan. Selanjutnya, data dapat diubah-ubah sebagaimana diinginkan untuk mengetahui dampak perubahanperubahan terhadap laba yang diharapkan.

Simamora (2012) menyatakan bahwa faktor-faktor yang perlu diperhatikan dalam melakukan analisis sensitivitas adalah sebagai berikut:
a. Perubahan harga jual
b. Perubahan biaya variabel
c. Perubahan biaya tetap
d. Perubahan simultan harga dan biaya
e. Pajak penghasilan

\section{METODE PENELITIAN}

Metode secara umum diartikan sebagai suatu cara yang tepat dalam melakukan sesuatu. Penelitian (reseach) merupakan rangkaian kegiatan ilmiah dalam rangka pemecahan suatu permasalahan (Azwar, 2010). Sehingga dapat dikatakan bahwa metode penelitian adalah suatu cara yang tepat dalam melakukan rangkaian kegiatan ilmiah dengan tujuan memecahkan suatu permasalahan.

Tugas Akhir merupakan salah satu bentuk laporan hasil penelitian. Untuk menghasilkan penulisan Tugas Akhir yang baik dan benar, serta menyajikan data yang akurat metode penelitian memiliki peran penting didalamnya. Metode penelitian meliputi klasifikasi data, metode pengumpulan data, metode analisis data, dan metode penulisan.

\section{Klasifikasi Data}

Data diklasifikasikan menjadi dua, yaitu klasifikasi data menurut sumbernya dan klasifikasi data menurut jenisnya.
a. Klasifikasi
data menurut
sumbernya
1. Data Primer

Data primer, atau data tangan pertama, adalah data yang diperoleh langsung dari subjek penelitian dengan mengenakan alat pengukuran atau alat pengambilan data langsung pada subjek sebagai sumber informasi yang dicari (Azwar, 2010).

2. Data Sekunder

Data sekunder, atau data tangan ke dua adalah data yang diperoleh lewat fihak lain, tidak langsung diperoleh oleh peneliti dari subjek penelitiannya (Azwar, 2010).

b. Klasifikasi data menurut jenisnya

\section{Data Kuantitatif}

Data kuantitatif adalah kumpulan angka-angka hasil observasi atau pengukuran (Soeratno \& Arsyad, 2008).

2. Data Kualitatif

Data kualitatif adalah data yang dicatat bukan dengan angka-angka tetapi dengan menggunakan klasifikasiklasifikasi (Soeratno \& Arsyad, 2008).

\section{Metode Pengumpulan Data}

Metode pengumpulan data yang digunakan dalam penelitian ini adalah sebagai berikut:

a. Wawancara

Wawancara adalah proses tanyajawab dalam penelitian yang berlangsung secara lisan dalam mana dua orang atau lebih bertatap muka mendengarkan secara langsung informasi-informasi atau keterangan-keterangan (Narbuko dan Achmadi 2010).

b. Dokumentasi

Dokumentasi adalah salah satu metode pengumpulan data dengan cara melakukan analisis terhadap semua catatan dan dokumen yang dimiliki oleh organisasi yang terpilih sebagai objek penelitian, atau data dari individu sebagai objek penelitian (Efferin et al., 2004).

\section{Metode Analisis Data}

Metode analisis data merupakan bagian dari proses pengujian data yang 
hasilnya digunakan sebagai bukti yang memadai untuk menarik kesimpulan penelitian. Tahap-tahap analisis yang akan dilakukan adalah sebagai berikut:

a. Pengklasifikasian biaya kedalam biaya tetap dan biaya variabel. Untuk biaya semivariabel dilakukan pemisahan antara biaya tetap dan biaya variabel yang terkandung didalamnya.

b. Perhitungan Margin Kontribusi dan Rasio Margin Kontribusi.

c. Analisis Titik Impas (Break Even Point).

d. Perhitungan target laba pada tahun 2017.

e. Perhitungan Margin Pengaman (Margin Of Safety).

f. Perhitungan Tingkat Operating Leverage

g. Perhitungan Titik Penutupan Usaha (Shut Down Point).

h. Analisis Sensitivitas.

Metode Penulisan

Metode penulisan yang digunakan dalam Tugas Akhir ini antara lain: a. Metode Deskripsi

Deskripsi merupakan suatu metode yang berupaya untuk menggambarkan sesuatu hal sesuai dengan keadaan yang sebenarnya (Keraf, 2004).

b. Metode Eksposisi

Tulisan eksposisi bertujuan untuk memberikan penjelasan atau informasi yang diuraikan dalam sebuah proses (Keraf, 2004).

ANALISIS DAN PEMBAHASAN

Volume dan Komposisi Penjualan CV Waringin Putih Semarang

CV Waringin Putih Semarang merupakan industri yang bergerak dalam pembuatan material bangunan berupa paving dan batako. Berbagai jenis paving yang diproduksi diantaranya Paving Holland, Paving Hexagonal, Paving Unipave, Grass Block, Topi Uskup dan Batako. Tabel 2 menyajikan komposisi penjualan CV Waringin Putih Semarang pada tahun 2016:

Tabel 2. Komposisi Penjualan CV Waringin Putih Semarang Tahun 2016

\begin{tabular}{|l|c|c|c|c|c|}
\hline \multicolumn{1}{|c|}{ Jenis Produk } & $\begin{array}{c}\text { Kuantitas } \\
\text { Penjualan } \\
\left(\mathrm{m}^{2}\right)\end{array}$ & $\begin{array}{c}\text { Harga Jual } \\
\text { per } \mathrm{m}^{2} \\
(\mathrm{Rp})\end{array}$ & $\begin{array}{c}\text { Total Penjualan } \\
(\mathrm{Rp})\end{array}$ & $\begin{array}{c}\text { Product } \\
\text { Mix } \\
(\%)\end{array}$ & $\begin{array}{c}\text { Sales } \\
\text { Mix } \\
(\%)\end{array}$ \\
\hline Holland $6 \mathrm{~cm} \mathrm{K200}$ & 29.745 & $68.000,00$ & $2.022 .660 .000,00$ & 52,80 & 47,74 \\
\hline Holland $6 \mathrm{~cm} \mathrm{K300}$ & 7.887 & $78.000,00$ & $615.186 .000,00$ & 14,00 & 14,52 \\
\hline Holland $8 \mathrm{~cm} \mathrm{K300}$ & 4.587 & $97.000,00$ & $444.939 .000,00$ & 8,14 & 10,50 \\
\hline Hexagonal & 4.242 & $72.000,00$ & $305.424 .000,00$ & 7,53 & 7,21 \\
\hline Unipave & 3.992 & $69.000,00$ & $275.448 .000,00$ & 7,09 & 6,50 \\
\hline Batako & 3.308 & $72.000,00$ & $238.176 .000,00$ & 5,87 & 5,62 \\
\hline Grass Block & 1.306 & $136.000,00$ & $177.616 .000,00$ & 2,32 & 4,19 \\
\hline Topi Uskup & 1.267 & $124.500,00$ & $157.741 .500,00$ & 2,25 & 3,72 \\
\hline \multicolumn{1}{|c|}{ Total } & 56.334 & & $4.237 .190 .500,00$ & 100,00 & 100,00 \\
\hline
\end{tabular}

Sumber: Data sekunder yang diolah, 2017

\section{Klasifikasi Biaya}

Langkah awal yang dilakukan dalam analisis biaya volume laba adalah menganalisis dan mengklasifikasikan biaya menjadi biaya tetap dan biaya variabel, serta memisahkan biaya campuran (semivariabel) kedalam biaya tetap dan biaya variabel. Tabel 3 menyajikan biaya-biaya yang dikeluarkan CV Waringin Putih Semarang selama tahun 2016 beserta klasifikasinya: 
Tabel 3. Data Biaya CV Waringin Putih Semarang Tahun 2016 Beserta Klasifikasinya

\begin{tabular}{|c|c|c|}
\hline Keterangan & Jumlah (Rp) & Klasifikasi Biaya \\
\hline Biaya Bahan Baku & $2.514 .515 .658,00$ & Variabel \\
\hline Biaya Tenaga Kerja Langsung & $219.271 .640,00$ & Variabel \\
\hline Biaya Tenaga Kerja Harian & $205.388 .000,00$ & Variabel \\
\hline Biaya Bahan Bakar & $59.159 .400,00$ & Variabel \\
\hline Biaya Pengiriman Barang & $16.107 .000,00$ & Variabel \\
\hline Biaya Kantor & $9.874 .350,00$ & Variabel \\
\hline Biaya Kerumahtanggaan & $5.913 .800,00$ & Variabel \\
\hline Biaya Reparasi dan Pemeliharaan Peralatan & $5.316 .000,00$ & Variabel \\
\hline Biaya Lain-lain & $3.468 .500,00$ & Variabel \\
\hline Biaya Gaji Karyawan Tetap & $354.000 .000,00$ & Tetap \\
\hline Biaya Internet & $9.000 .000,00$ & Tetap \\
\hline Biaya Pulsa Telepon & $4.800 .000,00$ & Tetap \\
\hline Biaya Penyusutan Bangunan & $56.050 .000,00$ & Tetap \\
\hline Biaya Penyusutan Kendaraan & $7.500 .000,00$ & Tetap \\
\hline Biaya Penyusutan Peralatan & $5.975 .000,00$ & Tetap \\
\hline Biaya Iklan & $3.561 .000,00$ & Tetap \\
\hline Biaya Listrik & $62.643 .127,00$ & Semivariabel \\
\hline Biaya Telepon & $4.926 .980,00$ & Semivariabel \\
\hline Biaya Reparasi dan Pemeliharaan Mesin & $6.076 .200,00$ & Semivariabel \\
\hline Biaya Reparasi dan Pemeliharaan Kendaraan & $16.810 .000,00$ & Semivariabel \\
\hline Total & $3.570 .356 .655,00$ & \\
\hline
\end{tabular}

(Sumber: Data Sekunder yang Diolah, 2017)

\section{Pemisahan Unsur Biaya Semivariabel}

Mengacu pada salah satu asumsi analisis biaya volume laba, yakni semua biaya diklasifikasikan sebagai biaya variabel dan biaya tetap, maka diperlukan pemisahan unsur biaya variabel dan biaya tetap yang terdapat dalam biaya semivariabel. Pemisahan unsur biaya semivariabel ini bertujuan untuk memperoleh hasil analisis yang tepat dan akurat.

Metode regresi kuadrat terkecil digunakan dalam pemisahan unsur biaya semivariabel pada CV Waringin Putih Semarang. Persamaan dasar metode regresi kuadrat terkecil adalah:

$$
\mathrm{Y}=\mathrm{a}+\mathrm{bX}
$$

Untuk menentukan biaya variabel (b), dapat dihitung dengan formula sebagai berikut:

$\mathrm{b}=\frac{\left(\mathrm{N} \times \sum \mathrm{XY}\right)-\left(\sum \mathrm{X} \times \sum \mathrm{Y}\right)}{\mathrm{N} \sum \mathrm{X}^{2}-\left(\sum \mathrm{X}\right)^{2}}$

Untuk menentukan biaya tetap (a), dapat dihitung dengan formula sebagai berikut:

$\mathrm{a}=\frac{\sum \mathrm{Y}-\mathrm{b} \sum \mathrm{X}}{\mathrm{N}}$

Keterangan:

$\mathrm{a}=$ Konstanta (menggambarkan biaya tetap per jumlah pengamatan)

$\mathrm{b}=$ Koefisien (menggambarkan biaya variabel per aktivitas)

$\mathrm{Y}=$ Biaya Campuran (semivariabel)

$\mathrm{X}=$ Aktivitas

$\mathrm{N}=$ Jumlah pengamatan

Tabel 4 menyajikan rincian biaya pada CV Waringin Putih Semarang tahun 2016 setelah adanya pemisahan biaya semivariabel beserta klasifikasinya: 
Tabel 4. Rincian Biaya pada CV Waringin Putih Semarang Tahun 2016 Setelah adanya Pemisahan Biaya Semivariabel

\begin{tabular}{|l|r|r|r|}
\hline \multicolumn{1}{|c|}{ Keterangan } & \multicolumn{1}{c|}{$\begin{array}{c}\text { Jumlah Biaya } \\
(\mathbf{R})\end{array}$} & $\begin{array}{c}\text { Biaya Tetap } \\
(\mathbf{R})\end{array}$ & \multicolumn{1}{c|}{$\begin{array}{c}\text { Biaya Variabel } \\
(\mathbf{R})\end{array}$} \\
\hline Biaya Bahan Baku & $2.514 .515 .658,00$ & & $2.514 .515 .658,00$ \\
\hline Biaya Tenaga Kerja Langsung & $219.271 .640,00$ & & $219.271 .640,00$ \\
\hline Biaya Tenaga Kerja Harian & $205.388 .000,00$ & & $205.388 .000,00$ \\
\hline Biaya Bahan Bakar & $59.159 .400,00$ & & $16.159 .400,00$ \\
\hline Biaya Pengiriman Barang & $16.107 .000,00$ & & $9.874 .350,00$ \\
\hline Biaya Kantor & $9.874 .350,00$ & & $5.913 .800,00$ \\
\hline Biaya Kerumahtanggaan & $5.913 .800,00$ & & $5.316 .000,00$ \\
\hline $\begin{array}{l}\text { Biaya Reparasi dan } \\
\text { Pemeliharaan Peralatan }\end{array}$ & $5.316 .000,00$ & & $3.468 .500,00$ \\
\hline Biaya Lain-lain & $3.468 .500,00$ & & \\
\hline Biaya Gaji Karyawan Tetap & $354.000 .000,00$ & $354.000 .000,00$ & \\
\hline Biaya Internet & $9.000 .000,00$ & $9.000 .000,00$ & \\
\hline Biaya Pulsa Telepon & $4.800 .000,00$ & $4.800 .000,00$ & \\
\hline Biaya Penyusutan Bangunan & $56.050 .000,00$ & $56.050 .000,00$ & \\
\hline Biaya Penyusutan Kendaraan & $7.500 .000,00$ & $7.500 .000,00$ & \\
\hline Biaya Penyusutan Peralatan & $5.975 .000,00$ & $5.975 .000,00$ & \\
\hline Biaya Iklan & $3.561 .000,00$ & $3.561 .000,00$ & \\
\hline Biaya Listrik & $62.643 .127,00$ & $46.664 .640,00$ & $15.978 .487,00$ \\
\hline Biaya Telepon & $4.926 .980,00$ & $576.000,00$ & $4.350 .980,00$ \\
\hline $\begin{array}{l}\text { Biaya Reparasi dan } \\
\text { Pemeliharaan Mesin }\end{array}$ & $6.076 .200,00$ & $3.574 .718,85$ & $2.501 .481,15$ \\
\hline $\begin{array}{l}\text { Biaya Reparasi dan } \\
\text { Pemeliharaan Kendaraan }\end{array}$ & $16.810 .000,00$ & $4.114 .006,42$ & $12.695 .993,58$ \\
\hline & $\mathbf{3 . 5 7 0 . 3 5 6 . 6 5 5 , 0 0}$ & $\mathbf{4 9 5 . 8 1 5 . 3 6 5 , 2 7}$ & $\mathbf{3 . 0 7 4 . 5 4 1 . 2 8 9 , 7 3}$ \\
\hline
\end{tabular}

(Sumber: Data Sekunder yang Diolah, 2017)

\section{Pengalokasian Biaya Variabel Pada Masing-masing Produk}

Jumlah biaya variabel setiap jenis produk tidak langsung dapat diketahui, sehingga diperlukan pengalokasian biaya variabel untuk masing-masing jenis produk. Adapun pengalokasian biaya variabel berdasarkan komposisi penjualan (sales mix) pada masing-masing jenis produk adalah sebagai berikut:
a. Holland $6 \mathrm{~cm} \mathrm{K200}$
$=47,74 \% \times \mathrm{Rp} 3.074 .541 .289,73$
$=\mathrm{Rp} 1.467 .786 .011,72$
b. Holland $6 \mathrm{~cm} \mathrm{K300}$
$=14,52 \% \times \mathrm{Rp} 3.074 .541 .289,73$
$=\mathrm{Rp} 446.423 .395,27$
c. Holland $8 \mathrm{~cm} \mathrm{K300}$
$=10,50 \% \times \mathrm{Rp} 3 \cdot 074.541 .289,73$
$=\mathrm{Rp} 322.826 .835,42$
d. Hexagonal
$=7,21 \% \times \mathrm{Rp} 3.074 .541 .289,73$
$=\mathrm{Rp} 221.674 .426,99$

e. Unipave $=6,50 \% \times \mathrm{Rp} 3.074 .541 .289,73$

$=\operatorname{Rp} 199.845 .183,83$

f. Batako

$=5,62 \% \times \operatorname{Rp} 3.074 .541 .289,73$

$=\operatorname{Rp} 172.789 .220,48$

g. Grass Block

$=4,19 \% \times \mathrm{Rp} 3.074 .541 .289,73$

$=\operatorname{Rp} 128.823 .280,04$

h. Topi Uskup

$$
=3,72 \% \text { x Rp3.074.541.289,73 }
$$

$=\operatorname{Rp} 114.372 .935,98$

Setelah biaya variabel dialokasikan pada masing-masing jenis produk, selanjutnya diperhitungkan biaya varibel per $\mathrm{m}^{2}$ untuk setiap jenis produk. Tabel 5 menyajikan perhitungan biaya variabel per $\mathrm{m}^{2}$ produk CV Waringin Putih Semarang. 
Tabel 5. Perhitungan Biaya Variabel per $\mathbf{m}^{2}$ Produk CV Waringin Putih Semarang Tahun

\begin{tabular}{|l|c|c|c|}
\hline \multicolumn{1}{|c|}{ Jenis Produk } & $\begin{array}{c}\text { Biaya Variabel } \\
(\mathrm{Rp})\end{array}$ & $\begin{array}{c}\text { Kuantitas } \\
\text { Penjualan } \\
\left(\mathbf{m}^{2}\right)\end{array}$ & $\begin{array}{c}\text { Biaya Variabel } \\
\text { per } \mathbf{~}^{2} \\
(\mathrm{Rp})\end{array}$ \\
\hline \multicolumn{1}{|c|}{$(1)$} & $(2)$ & $(3)$ & $(4)=(2):(3)$ \\
\hline Holland 6 cm K200 & $1.467 .786 .011,72$ & 29.745 & $49.345,64$ \\
\hline Holland 6 cm K300 & $446.423 .395,27$ & 7.887 & $56.602,43$ \\
\hline Holland 8 cm K300 & $322.826 .835,42$ & 4.587 & $70.378,64$ \\
\hline Hexagonal & $221.674 .426,99$ & 4.242 & $52.257,05$ \\
\hline Unipave & $199.845 .183,83$ & 3.992 & $50.061,42$ \\
\hline Batako & $172.789 .220,48$ & 3.308 & $52.233,74$ \\
\hline Grass Block & $128.823 .280,04$ & 1.306 & $98.639,57$ \\
\hline Topi Uskup & $114.372 .935,98$ & 1.267 & $90.270,67$ \\
\hline \multicolumn{1}{|c|}{ Total } & $\mathbf{3 . 0 7 4 . 5 4 1 . 2 8 9 , 7 3}$ & $\mathbf{5 6 . 3 3 4}$ & \\
\hline
\end{tabular}

(Sumber: Data Sekunder yang Diolah, 2017)

Margin Kontribusi Rata-Rata Tertimbang dan Rasio Margin Kontribusi

Margin Kontribusi atau laba kontribusi merupakan selisih antara penjualan dengan biaya variabel. Berikut perhitungan margin kontribusi CV Waringin Putih Semarang tahun 2016:

Margin Kontribusi $=$ Penjualan - Biaya Variabel

$=\operatorname{Rp} 4.237 .190 .500,00-\operatorname{Rp} 3.074 .541 .289,73$

$=\operatorname{Rp} 1.162 .649 .210,27$

\section{Tabel 6. Perhitungan Margin Kontribusi per $\mathrm{m}^{2}$ Produk CV Waringin Putih Semarang} Tahun 2016

\begin{tabular}{|l|c|c|c|}
\hline \multicolumn{1}{|c|}{ Jenis Produk } & $\begin{array}{c}\text { Harga Jual } \\
\text { per m }{ }^{2} \\
(\mathrm{Rp})\end{array}$ & $\begin{array}{c}\text { Biaya Variabel } \\
\text { per }^{2} \\
(\mathrm{Rp})\end{array}$ & $\begin{array}{c}\text { Margin Kontribusi } \\
\text { per } \mathrm{m}^{2} \\
(\mathrm{Rp})\end{array}$ \\
\hline \multicolumn{1}{|c|}{$(1)$} & $(2)$ & $(3)$ & $(4)=(2)-(3)$ \\
\hline Holland 6 cm K200 & $68.000,00$ & $49.345,64$ & $18.654,36$ \\
\hline Holland 6 cm K300 & $78.000,00$ & $56.602,43$ & $21.397,57$ \\
\hline Holland 8 cm K300 & $97.000,00$ & $70.378,64$ & $26.621,36$ \\
\hline Hexagonal & $72.000,00$ & $52.257,05$ & $19.742,95$ \\
\hline Unipave & $69.000,00$ & $50.061,42$ & $18.938,58$ \\
\hline Batako & $72.000,00$ & $52.233,74$ & $19.766,26$ \\
\hline Grass Block & $136.000,00$ & $98.639,57$ & $37.360,43$ \\
\hline Topi Uskup & $124.500,00$ & $90.270,67$ & $34.229,33$ \\
\hline
\end{tabular}

(Sumber: Data Sekunder yang Diolah, 2017)

Bagi Perusahaan yang memproduksi lebih dari satu jenis produk, margin kontribusi yang digunakan dalam penerapan analisis biaya volume laba adalah margin
Rasio Margin Kontribusi $=$ Margin Kontribusi

Penjualan

$\frac{\operatorname{Rp} 1.162 .649 .210,27}{\operatorname{Rp} 4.237 .190 .500,00} \%$

Rasio Margin Kontribusi $=27,44 \%$

Berikut perhitungan margin kontribusi per $\mathrm{m}^{2}$ masing-masing jenis produk CV Waringin Putih Semarang:
Rasio Margin Kontribusi $=$ 


\section{Tabel 7. Perhitungan Margin Kontribusi Rata-rata Tertimbang CV Waringin Putih} Semarang Tahun 2016

\begin{tabular}{|l|c|c|r|}
\hline \multicolumn{1}{|c|}{ Jenis Produk } & $\begin{array}{c}\text { Margin } \\
\text { Kontribusi } \\
\text { per m }{ }^{2} \\
(\mathrm{Rp})\end{array}$ & $\begin{array}{c}\text { Product Mix } \\
(\%)\end{array}$ & $\begin{array}{c}\text { Margin Kontribusi } \\
\text { Rata-rata } \\
\text { Tertimbang per m }\end{array}$ \\
\hline$(1)$ & $(2)$ & $(3)$ & $(4)=(2) \times(3)$ \\
\hline Holland 6 cm K200 & $18.654,36$ & 52,80 & $9.849,50$ \\
\hline Holland 6 cm K300 & $21.397,57$ & 14,00 & $2.995,66$ \\
\hline Holland 8 cm K300 & $26.621,36$ & 8,14 & $2.166,98$ \\
\hline Hexagonal & $19.742,95$ & 7,53 & $1.486,64$ \\
\hline Unipave & $18.938,58$ & 7,09 & $1.342,75$ \\
\hline Batako & $19.766,26$ & 5,87 & $1.160,28$ \\
\hline Grass Block & $37.360,43$ & 2,32 & 866,76 \\
\hline Topi Uskup & $34.229,33$ & 2,25 & 770,16 \\
\hline \multicolumn{2}{|c|}{ Margin Kontribusi Rata-rata Tertimbang } & $\mathbf{2 0 . 6 3 8 , 7 3}$ \\
\hline
\end{tabular}

Analisis Titik Impas (Break Even Point)

Perhitungan Break Even Point bagi perusahaan yang menjual lebih dari satu produk adalah sebagai berikut:

Titik Impas (Unit)

$=$

Biaya Tetap Total

Margin Kontribusi Rata-rata Tertimbang Titik Impas (Rp)

$=$

\section{Biaya Tetap Total}

Rasio Margin Kontribusi Rata-rata Tertimbang Berikut perhitungan Break Even

Point $\left(\mathrm{m}^{2}\right)$ CV Waringin Putih Semarang tahun 2016:

Titik Impas $\left(\mathrm{m}^{2}\right)$

$=\frac{\text { Biaya Tetap Total }}{\text { Margin Kontribusi Rata-rata Tertimbang }}$

Titik Impas $\left(\mathrm{m}^{2}\right)=\frac{\mathrm{Rp} 495.815 .365,27}{\mathrm{Rp} 20.638 .73}$

Titik Impas $\left(\mathrm{m}^{2}\right)=24.023,54=24.024 \mathrm{~m}^{2}$

Berikut perhitungan Break Even

Point (Rp) CV Waringin Putih Semarang tahun 2016:

Titik Impas (Rp)

$$
=\frac{\text { Biaya Tetap Total }}{\text { Rasio Margin Kontribusi Rata-rata Tertimbang }}
$$

Titik Impas $(\mathrm{Rp})=\frac{\mathrm{Rp} 495.815 .365,27}{27.44 \%}$

Titik Impas $(\mathrm{Rp})=\mathrm{Rp} 1.806 .907 .307,84$

Berdasarkan perhitungan Break

Even Point di atas, diketahui Break Even

Point CV Waringin Putih Semarang berada pada tingkat penjualan $24.024 \mathrm{~m}^{2}$ atau dengan nilai penjualan sebesar Rp1.806.907.307,84

\section{Perencanaan Laba}

Pada tahun 2017 pihak manajemen CV Waringin Putih Semarang menghendaki peningkatan laba sebesar $30 \%$ dari laba tahun 2016. Peningkatan jumlah laba tersebut didasari atas keberhasilan CV Waringin Putih Semarang pada tahun 2016 memperoleh peningkatan laba sebesar $25 \%$ dari laba tahun 2015 dan ingin meningkatkan perolehan laba pada tahun 2017. Dalam membuat perencanaan laba tahun 2017, CV Waringin Putih Semarang menggunakan data realisasi penjualan dan biaya tahun 2016 sebagai acuan. Berikut perhitungan target laba CV Waringin Putih Semarang untuk tahun 2017:

Target Laba Tahun 2017

$=130 \% \times$ Laba Tahun 2016

$=130 \% \times \mathrm{Rp} 666.833 .845,00$

$=\mathrm{Rp} 866.883 .998,50$

Untuk mencapai target laba tersebut berikut estimasi penjualan yang harus dicapai oleh CV Waringin Putih Semarang Tahun 2017:

Unit penjualan untuk mencapai target laba $=$

$$
\text { Biaya tetap + Target laba }
$$

Margin kontribusi Rata-rata Tertimbang Unit penjualan untuk mencapai target laba $=\frac{\operatorname{Rp} 495.815 .365,27+\mathrm{Rp} 866.883 .998,50}{\mathrm{Rp} 20.638,73}$

Unit penjualan untuk mencapai target laba $=\frac{\operatorname{Rp} 1.362 .699 .363,77}{\operatorname{Rp} 20.638,73}=66.026,32=66.026 \mathrm{~m}^{2}$

Dari hasil perhitungan estimasi penjualan di atas, dapat diketahui untuk mencapai target laba pada tahun 2017, CV Waringin Putih Semarang harus melakukan penjualan sebanyak $66.026 \mathrm{~m}^{2}$ paving, dan batako, atau senilai dengan 
Rp4.966.205.500,00. Dengan kata lain, CV Waringin Putih Semarang harus meningkatkan penjualannya sebesar sebanyak $9.692 \mathrm{~m}^{2}$ dengan nilai penjualan Rp729.015.000,00 atau sebesar $17,21 \%$ dari tahun 2016.

\section{Margin Pengaman (margin of safety)}

Perhitungan margin pengaman $(\mathrm{Rp})$

CV Waringin Putih Semarang tahun 2017 adalah sebagai berikut:

Margin Pengaman (Rp)

$=$ Penjualan dianggarkan - Penjualan impas

Margin Pengaman ( $\mathrm{Rp})$

$=\mathrm{Rp} 4.966 .205 .500,00-\mathrm{Rp} 1.806 .907 .307,84$

$=$ Rp3.159.298.192,16

Perhitungan margin pengaman $\left(\mathrm{m}^{2}\right)$ CV Waringin Putih Semarang tahun 2017 adalah sebagai berikut:

Margin Pengaman $\left(\mathrm{m}^{2}\right)=$ Penjualan dianggarkan - Penjualan impas

Margin Pengaman $\left(\mathrm{m}^{2}\right)=66.026-24.024$

$$
=42.002 \mathrm{~m}^{2}
$$

Perhitungan persentase margin pengaman CV Waringin Putih Semarang tahun 2017 adalah sebagai berikut:

$\%$ margin pengaman $=\frac{\text { Margin pengaman }(\mathrm{Rp})}{\text { Penjualan dianggarkan }} \%$

$\%$ margin pengaman $=\frac{\mathrm{Rp} 3.159 .298 .192,16}{\mathrm{Rp} 4.966 .205 .500,00} \%$

Persentase margin pengaman $=63,62 \%$

Pengungkit Operasi (Operating Leverage)

Perhitungan tingkat operating

leverage CV Waringin Putih Semarang tahun 2016 adalah sebagai berikut:

Tingkat Leverage Operasi $=$ Margin Kontribusi

Laba Neto

Tingkat Leverage Operasi $=$

Rp1.162.649.210,27

Rp666.833.845,00

Tingkat Leverage Operasi $=1,74$

Berdasarkan perhitungan tingkat operating leverage di atas, dapat diketahui bahwa suatu perubahan penjualan akan mengakibatkan perubahan 1,74 kali lipat terhadap laba pada CV Waringin Putih Semarang. Dengan demikian, diketahui apabila laba pada tahun 2017 meningkat sebesar 30\% dari laba tahun 2016, maka jumlah penjualan CV Waringin Putih Semarang akan meningkat $17,21 \%(30 \% / 1,74)$ atau sebesar Rp4.966.205.500,00, dengan selisih pembulatan Rp205.485,05.

Titik Penutupan Usaha (Shut Down Point)

Perhitungan shut down point bagi perusahaan yang menjual lebih dari satu produk adalah sebagai berikut:

SDP (Unit)

$=$

$\frac{\text { Biaya Tetap Tunai }}{\text { Margin Kontribusi Rata-rata Tertimbang }}$ $\mathrm{SDP}(\mathrm{Rp})$

$=$

Biaya Tetap Tunai

Rasio Margin Kontribusi Rata-rata Tertimbang Berikut perhitungan titik penutupan usaha (shut down point) pada CV Waringin Putih Semarang tahun 2016:

Tabel 8. Rincian Biaya Tetap Tunai CV Waringin Putih Semarang Tahun 2016

\begin{tabular}{|c|c|}
\hline Keterangan & $\begin{array}{c}\text { Jumlah Biaya } \\
\text { (Rp) }\end{array}$ \\
\hline Biaya Gaji Karyawan Tetap & $354.000 .000,00$ \\
\hline Biaya Internet & $9.000 .000,00$ \\
\hline Biaya Pulsa Telepon & $4.800 .000,00$ \\
\hline Biaya Iklan & $3.561 .000,00$ \\
\hline Biaya Listrik & $46.664 .640,00$ \\
\hline Biaya Telepon & $576.000,00$ \\
\hline Biaya Reparasi dan Pemeliharaan Mesin & $3.574 .718,85$ \\
\hline Biaya Reparasi dan Pemeliharaan Kendaraan & $4.114 .006,42$ \\
\hline Total & $426.290 .365,27$ \\
\hline
\end{tabular}

(Sumber: Data Sekunder yang Diolah, 2017)

Perhitungan shut down point $\left(\mathrm{m}^{2}\right) \mathrm{CV}$

Waringin Putih Semarang:

$$
\begin{aligned}
& \operatorname{SDP}\left(\mathrm{m}^{2}\right)=\frac{\text { Biaya Tetap Tunai }}{\text { Margin Kontribusi Rata-rata Tertimbang }} \\
& \operatorname{SDP}\left(\mathrm{m}^{2}\right)=\frac{\text { Rp426.290.365,27 }}{\text { Rp20.638,73 }}
\end{aligned}
$$

$\operatorname{SDP}\left(\mathrm{m}^{2}\right)=20.654,87=20.655 \mathrm{~m}^{2}$

Perhitungan shut down point ( $\mathrm{Rp})$

CV Waringin Putih Semarang:

$\mathrm{SDP}(\mathrm{Rp})$

$=\frac{\text { Biaya Tetap Tunai }}{\text { Rasio Margin Kontribusi Rata-rata Tertimbang }}$ 


$$
\begin{aligned}
& \operatorname{SDP}(\operatorname{Rp})=\frac{\operatorname{Rp} 426.290 .365,27}{27,44 \%} \\
& \operatorname{SDP}(\operatorname{Rp})=\operatorname{Rp} 1.553 .536 .316,58
\end{aligned}
$$

\section{Grafik Biaya Volume Laba}

Grafik biaya volume laba pada Gambar 1 menggambarkan:

a. Titik impas (break even point) berada pada perpotongan garis total penjualan dengan garis total biaya. Untuk mencapai titik impas, CV Waringin Putih Semarang harus menjual $24.024 \mathrm{~m}^{2}$ dengan nilai penjualan sebesar Rp1.806.907.307,84. Area dibawah titik impas merupakan area rugi, sedangkan area diatas titik impas merupakan area laba.

b. Titik penutupan usaha (shut down point) berada pada perpotongan garis total penjualan dengan garis total biaya tunai. Untuk tetap dapat menjalankan usahanya CV Waringin Putih Semarang minimal harus menjual $20.655 \mathrm{~m}^{2}$ dengan nilai penjualan sebesar Rp1.553.536.316,58. c. CV Waringin Putih Semarang menargetkan jumlah laba pada tahun 2017 meningkat sebesar 30\% dari laba 2016 atau memperoleh laba sebesar Rp866.883.998,50. Jumlah laba tersebut dapat dicapai perusahaan dengan melakukan penjualan sebesar Rp4.966.205.500,00 atau sebanyak $66.026 \mathrm{~m}^{2}$ paving dan batako dengan total biaya yang dikeluarkan adalah sebesar Rp4.099.336.043,28.

d. Margin pengaman (margin of safety) berada diantara total penjualan yang dianggarkan sebesar Rp4.966.205.500,00 dengan total penjualan pada titik impas sebesar Rp1.806.907.307,84. Margin pengaman ini menunjukkan nilai penjualan sebesar Rp3.159.298.192,16 atau sebesar $63,62 \%$ dari penjualan yang dianggarkan dengan jumlah penjualan produk sebanyak 42.002 $\mathrm{m}^{2}$.

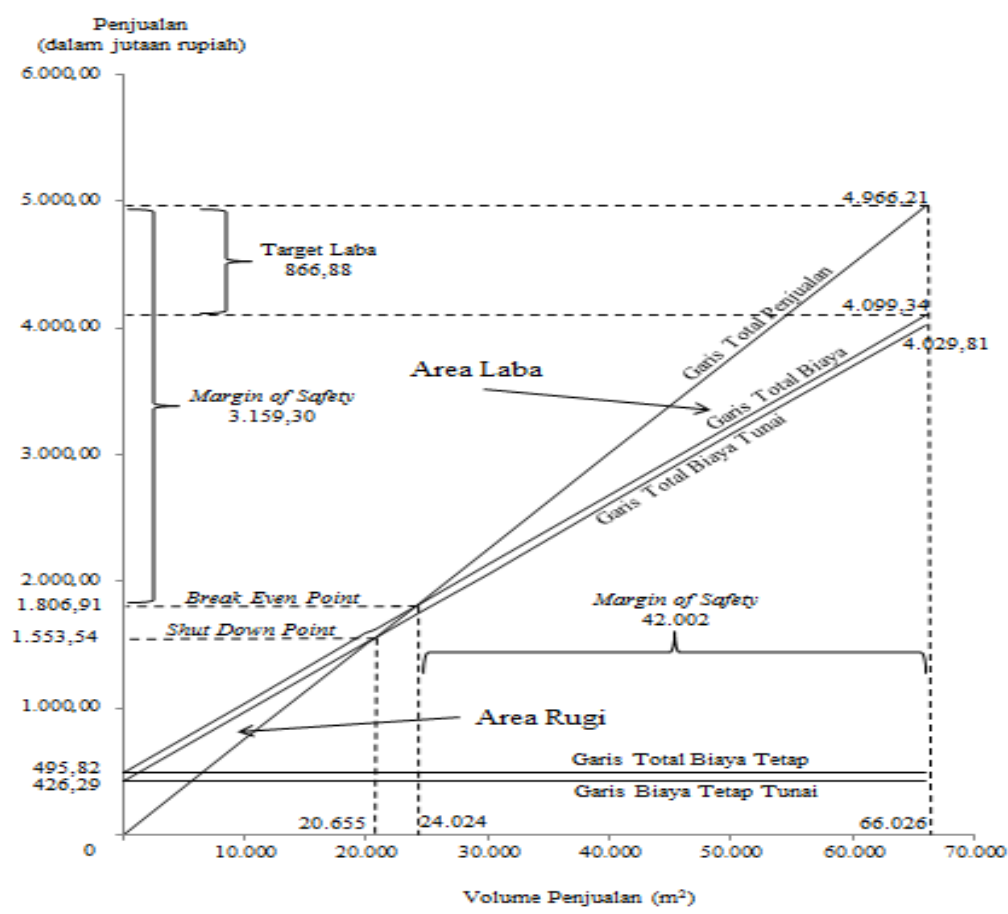

Gambar 1. Grafik Biaya Volume Laba CV Waringin Putih Semarang

\section{Analisis Sensitivitas}

Analisis faktor-faktor yang dapat mempengaruhi laba perusahaan dikenal dengan analisis sensitivitas. Berikut merupakan analisis sensitivitas terhadap asumsi-asumsi yang memperlihatkan 
perubahan faktor-faktor yang dapat mempengaruhi laba pada CV Waringin Putih Semarang.

Tabel 9. Perhitungan Analisis Sensitivitas akibat Perubahan Harga Jual pada CV Waringin Putih Semarang Tahun 2016

\begin{tabular}{|c|c|c|c|c|}
\hline No & Keterangan & $\begin{array}{l}\text { Turun } 7 \% \\
\text { (Rp) }\end{array}$ & $\begin{array}{l}\text { Awal } \\
(\mathrm{Rp})\end{array}$ & $\begin{array}{c}\text { Naik } 7 \% \\
\text { (Rp) }\end{array}$ \\
\hline (1) & Penjualan & $3.940 .587 .165,00$ & $4.237 .190 .500,00$ & $4.533 .793 .835,00$ \\
\hline (2) & Biaya Variabel & $3.074 .541 .289,73$ & $3.074 .541 .289,73$ & $3.074 .541 .289,73$ \\
\hline (3) & Margin Kontribusi Total = (1) - (2) & $866.045 .875,27$ & $1.162 .649 .210,27$ & $1.459 .252 .545,27$ \\
\hline (4) & Biaya Tetzp & 495.815 .365 .27 & $495.815 .365,27$ & $495.815 .365,27$ \\
\hline (5) & Laba Sebelum Pajak = (3) - (4) & $370.230 .510,00$ & $666.833 .845,00$ & $963.437 .180,00$ \\
\hline (6) & Margin Kontribusi Rata-rata Tertimbang & $15.373,58$ & $20.638,73$ & $25.903,87$ \\
\hline (7) & $\begin{array}{l}\text { Rasio Margin Kontribusi } \\
\text { Rata-rata Tertimbang = (3): (1) }\end{array}$ & $21,98 \%$ & $27,44 \%$ & $32,19 \%$ \\
\hline \multicolumn{5}{|c|}{ TitikImpas } \\
\hline (8) & Penjualan $\left(\mathrm{m}^{2}\right)=(4):(6)$ & 32.251 & 24.024 & 19.141 \\
\hline (9) & Penjualan $(R p)=(4):(7)$ & $2.255 .756 .893,86$ & $1.806 .907 .307,84$ & $1.540 .277 .618,11$ \\
\hline \multicolumn{5}{|c|}{ Penjualan Target Laba } \\
\hline$(10)$ & Target Laba $130 \%$ Laba 2016 & $866.883 .998,50$ & $866.883 .998,50$ & $866.883 .998,50$ \\
\hline (11) & Penjualan $\left(\mathrm{m}^{2}\right)=\{(4)+(10)\}:(6)$ & 88.639 & 66.026 & 52.606 \\
\hline (12) & Penjualan $(\mathrm{Rp})=\{(4)+(10)\}:(7)$ & $6.199 .724 .129,98$ & $4.966 .205 .500,00$ & $4.233 .300 .291,30$ \\
\hline \multicolumn{5}{|c|}{ ShutDown Point } \\
\hline (13) & Biaya Tetap Tunai (Rp) & $426.290 .365,27$ & $426.290 .365,27$ & $426.290 .365,27$ \\
\hline (14) & Penjualan $\left(\mathrm{m}^{2}\right)=(13):(6)$ & 27.729 & 20.655 & 16.457 \\
\hline (15) & Penjualan $(\mathrm{Rp})=(13):(7)$ & $1.939 .446 .611,78$ & $1.553 .536 .316,58$ & $1.324 .294 .393,51$ \\
\hline \multicolumn{5}{|c|}{ Perubahan TitikImpas } \\
\hline$(16)$ & Dalam m² & $(+) 34,25 \%$ & $0,00 \%$ & $(-) 20,33 \%$ \\
\hline$(17)$ & Dalam Rupiah & $(+) 24,84 \%$ & $0,00 \%$ & $(-) 14,76 \%$ \\
\hline \multicolumn{5}{|c|}{ Perubahan Target Laba } \\
\hline (18) & Dalam m² & $(+) 34,25 \%$ & $0,00 \%$ & $(-) 20,33 \%$ \\
\hline (19) & Dalam Rupiah & $(+) 24,84 \%$ & $0,00 \%$ & $(-) 14,76 \%$ \\
\hline \multicolumn{5}{|c|}{ Perubahan Shut Down Point } \\
\hline$(20)$ & Dalam m² & $(+) 34,25 \%$ & $0,00 \%$ & $(-) 20,33 \%$ \\
\hline (21) & Dalam Rupiah & $(+) 24,84 \%$ & $0,00 \%$ & $(-) 14,76 \%$ \\
\hline
\end{tabular}

b. Analisis Sensitivitas Akibat Perubahan

Biaya Variabel Sebesar 9\%.

Tabel 10. Perhitungan Analisis Sensitivitas akibat Perubahan Biaya Variabel pada CV Waringin Putih Semarang Tahun 2016

\begin{tabular}{|c|c|c|c|c|}
\hline No & Keterangan & $\begin{array}{l}\text { Turun } 9 \% \\
\text { (Rp) }\end{array}$ & $\begin{array}{l}\text { Awal } \\
\text { (Rp) }\end{array}$ & $\begin{array}{l}\text { Naik } 9 \% \\
(\text { Rp) }\end{array}$ \\
\hline (1) & Penjualan & $4.237 .190 .500,00$ & $4.237 .190 .500,00$ & $4.237 .190 .500,00$ \\
\hline (2) & Biaya Variabel & $2.797 .832 .573,65$ & $3.074 .541 .289,73$ & $3.351 .250 .005,81$ \\
\hline (3) & Margin Kontribusi Total $=(1)-(2)$ & $1.439 .357 .926,35$ & $1.162 .649 .210,27$ & $885.940 .494,19$ \\
\hline (4) & Biaya Tetap & $495.815 .365,27$ & $495.815 .365,27$ & $495.815 .365,27$ \\
\hline (5) & Laba Sebelum Pajak = (3) - (4) & $943.542 .561,08$ & $666.833 .845,00$ & $390.125 .128,92$ \\
\hline (6) & Margin Kontribusi Rata-rata Tertimbang & $25.550,72$ & $20.638,73$ & $15.726,74$ \\
\hline (7) & $\begin{array}{l}\text { Rasio Margin Kontribusi } \\
\text { Rata-rata Tertimbang = (3): (1) }\end{array}$ & $33,97 \%$ & $27,44 \%$ & $20,91 \%$ \\
\hline \multicolumn{5}{|c|}{ Titik Impas } \\
\hline$(8)$ & Penjualan $\left(\mathrm{m}^{2}\right)=(4):(6)$ & 19.405 & 24.024 & 31.527 \\
\hline (9) & Penjualan $(\mathrm{Rp})=(4):(7)$ & $1.459 .568 .340,51$ & $1.806 .907 .307,84$ & $2.371 .187 .782,26$ \\
\hline \multicolumn{5}{|c|}{ Penjualan Target Laba } \\
\hline$(10)$ & Target Laba $130 \%$ Laba 2016 & $866.883 .998,50$ & $866.883 .998,50$ & $866.883 .998,50$ \\
\hline (11) & Penjualan $\left(\mathrm{m}^{2}\right)=\{(4)+(10)\}:(6)$ & 53.333 & 66.026 & 86.649 \\
\hline$(12)$ & Penjualan $(R p)=\{(4)+(10)\}:(7)$ & $4.011 .478 .845,36$ & $4.966 .205 .500,00$ & $6.516 .974 .480,01$ \\
\hline \multicolumn{5}{|c|}{ ShutDown Point } \\
\hline (13) & Biaya Tetap Tunai (Rp) & $426.290 .365,27$ & $426.290 .365,27$ & $426.290 .365,27$ \\
\hline (14) & Penjualan $\left(\mathrm{m}^{2}\right)=(13):(6)$ & 16.684 & 20.655 & 27.106 \\
\hline (15) & Penjualan $(R p)=(13):(7)$ & $1.254 .902 .458,85$ & $1.553 .536 .316,58$ & $2.038 .691 .369,06$ \\
\hline \multicolumn{5}{|c|}{ Perubahan TitikImpas } \\
\hline (16) & Dalam $m^{2}$ & $(-) 19,22 \%$ & $0,00 \%$ & $(+) 31,23 \%$ \\
\hline$(17)$ & Dalam Rupiah & $(-) 19,22 \%$ & $0,00 \%$ & $(+) 31,23 \%$ \\
\hline \multicolumn{5}{|c|}{ Perubahan Target Laba } \\
\hline (18) & Dalam m² & $(-) 19,22 \%$ & $0,00 \%$ & $(+) 31,23 \%$ \\
\hline (19) & Dalam Rupiah & $(-) 19,22 \%$ & $0,00 \%$ & $(+) 31,23 \%$ \\
\hline \multicolumn{5}{|c|}{ Perubahan Shut Down Point } \\
\hline$(20)$ & Dalam $\mathrm{m}^{2}$ & $(-) 19,22 \%$ & $0,00 \%$ & $(+) 31,23 \%$ \\
\hline (21) & Dalam Rupiah & $(-) 19,22 \%$ & $0,00 \%$ & $(+) 31,23 \%$ \\
\hline
\end{tabular}


c. Analisis sensitivitas akibat perubahan simultan harga jual dan biaya variabel

Tabel 11. Perhitungan Analisis Sensitivitas akibat Perubahan Simultan Harga Jual dan Biaya Variabel pada CV Waringin Putih Semarang Tahun 2016

\begin{tabular}{|c|c|c|c|c|}
\hline No & Keterangan & $\begin{array}{l}\text { Turun } \\
(\mathrm{Rp})\end{array}$ & $\begin{array}{l}\text { Awal } \\
\text { (Rp) }\end{array}$ & $\begin{array}{l}\text { Naik } \\
\text { (Rp) }\end{array}$ \\
\hline (1) & Penjualan $(7 \%)$ & $3.940 .587 .165,00$ & $4.237 .190 .500,00$ & $4.533 .793 .835,00$ \\
\hline (2) & Biaya Variabel $(9 \%)$ & $2.797 .832 .573,65$ & $3.074 .541 .289,73$ & $3.351 .250 .005,81$ \\
\hline (3) & Margin Kontribusi Total = (1)-(2) & $1.142 .754 .591,35$ & $1.162 .649 .210,27$ & $1.182 .543 .829,19$ \\
\hline (4) & Biaya Tetzp & $495.815365,27$ & $495.815365,27$ & $495.815 .365,27$ \\
\hline (5) & Laba Sebelvm Pajak=(3) - (4) & $646.939 .226,08$ & $666.833 .845,00$ & $686.728 .463,92$ \\
\hline (6) & Margin Kontribusi Rata-rata Tertimbang & $20.285,57$ & $20.638,73$ & $20.991,89$ \\
\hline (7) & $\begin{array}{l}\text { Rasio Margin Kontribusi } \\
\text { Rata-rata Tertimbang }=(3):(1)\end{array}$ & $29,00 \%$ & $27,44 \%$ & $26,08 \%$ \\
\hline \multicolumn{5}{|c|}{ TitikImpas } \\
\hline (8) & Penjualan $\left(m^{2}\right)=(4):(6)$ & 24.442 & 24.024 & 23.619 \\
\hline (9) & Penjualan $(R p)=(4):(7)$ & $1.709 .708 .156,10$ & $1.806 .907 .307,84$ & $1.901 .132 .535,54$ \\
\hline \multicolumn{5}{|c|}{ Penjualan Target Laba } \\
\hline (10) & Target Laba $130 \%$ Laba 2016 & $866.883 .998,50$ & $866.883 .998,50$ & $866.883 .998,50$ \\
\hline (11) & Penjualan $\left(\mathrm{m}^{2}\right)=\{(4)+(10)\}:(6)$ & 67.176 & 66.026 & 64.916 \\
\hline (12) & Penjualan $(R p)=\{(4)+(10)\}:(7)$ & $4.698 .963 .323,34$ & $4.966 .205 .500,00$ & $5.225 .074 .247,58$ \\
\hline \multicolumn{5}{|c|}{ ShutDownPoint } \\
\hline (13) & Biaya Tet $₫$ Tunai (Rp) & $426.290 .365,27$ & $426.290 .365,27$ & $426.290 .365,27$ \\
\hline (14) & Penjualan $\left(\mathrm{m}^{2}\right)=(13):(6)$ & 21.014 & 20.655 & 20.307 \\
\hline (15) & Penjualan $(R p)=(13):(7)$ & $1.469 .966 .776,79$ & $1.553 .536 .316,58$ & $1.634 .548 .946,59$ \\
\hline \multicolumn{5}{|c|}{ Perubahan TitikImpas } \\
\hline (16) & Dalam m² & $(+) 1,74 \%$ & $0,00 \%$ & $(-) 1,68 \%$ \\
\hline (17) & Dalam Rupiah & $(-) 5,38 \%$ & $0,00 \%$ & $(+) 5,21 \%$ \\
\hline \multicolumn{5}{|c|}{ Perubahan Target Laba } \\
\hline (18) & Dalam m² & $(+) 1,74 \%$ & $0,00 \%$ & $(-) 1,68 \%$ \\
\hline (19) & Dalam Rupiah & $(-) 5,38 \%$ & $0,00 \%$ & $(+) 5,21 \%$ \\
\hline \multicolumn{5}{|c|}{ Perubahan Shut Down Point } \\
\hline$(20)$ & Dalam m ${ }^{2}$ & $(+) 1,74 \%$ & $0,00 \%$ & $(-) 1,68 \%$ \\
\hline (21) & Dalam Rupiah & $(-) 5,38 \%$ & $0,00 \%$ & $(+) 5,21 \%$ \\
\hline
\end{tabular}

(Sumber: Data Sekunder yang Diolah, 2017)

\section{KESIMPULAN}

Analisis biaya volume laba sebagai alat perencanaan laba pada CV Waringin Putih Semarang telah dilakukan pada bab 4, maka dapat diambil kesimpulan sebagai berikut:

1. Total margin kontribusi pada CV Waringin Putih Semarang tahun 2016 adalah Rp1.162.649.210,27, dengan Margin Kontribusi Rata-rata Tertimbang adalah Rp20.638,73 dan Rasio Margin Kontribusi Rata-rata Tertimbang adalah 27,44\%.

2. Penjualan pada titik impas (break even point) CV Waringi Putih Semarang tahun 2016 adalah 24.024 $\mathrm{m}^{2}$ senilai dengan Rp1.806.907.307,84.

3. Total penjualan untuk mencapai target laba tahun 2017 adalah 66.026 $\mathrm{m}^{2}$ senilai dengan $\mathrm{Rp} 4.966 .205 .500,00$ atau meningkat sebesar $17,21 \%$ dari penjualan tahun 2016 .

4. Besarnya margin pengaman (margin of safety) pada CV Waringi Putih Semarang tahun 2017 adalah sebesar $63,62 \%$ dengan nilai penjualan sebesar Rp3.159.298.192,16 atau sebanyak $42.002 \mathrm{~m}^{2}$.
5. Penjualan pada titik penutupan usaha (shut down point) pada CV Waringi Putih Semarang tahun 2016 adalah $20.655 \mathrm{~m}^{2}$ senilai dengan Rp1.553.536.316,58. Besarnya tingkat operating leverage pada CV Waringin Putih Semarang tahun 2016 adalah 1,74 .

6. Turunnya margin kontribusi sebagai akibat dari penurunan harga atau peningkatan biaya variabel berdampak pada meningkatnya penjualan untuk mencapai titik impas, target laba, dan shut down point. Meningkatnya margin kontribusi sebagai akibat dari peningkatan harga jual atau penurunan biaya variabel menyebabkan turunnya penjualan untuk mencapai titik impas, target laba dan shut down poin. Apabila harga jual dan biaya variabel turun secara simultan, maka kuantitas penjualan akan meningkat sedangkan total penjualan akan menurun untuk mencapai titik impas, target laba, dan shut down point. Sebaliknya, apabila harga jual dan biaya variabel meningkat secara simultan, maka 
kuantitas penjualan akan menurun tetapi total penjualan akan meningkat untuk mencapai titik impas, target laba, dan shut down point.

\section{DAFTAR PUSTAKA}

Azwar, Saifuddin. 2010. Metode Penelitian. Yogyakarta: Pustaka Pelajar.

Efferin, Sujoko, dkk. 2004. Metode Penelitian Untuk Akuntansi. Malang: Bayumedia Publishing.

Garrison, dkk. 2013. Akuntansi Manajerial Edisi 14 Buku 1. Jakarta: Salemba Empat.

Hansen, Don R. dan Maryanne M. Mowen. 2009. Akuntansi Manajerial. Jakarta: Salemba Empat.

Keraf, Gorys. 2004. Komposisi. Jakarta: Nusa Indah.

Kusuma, Hadri, dkk. 2013. Akuntansi Manajemen. Yogyakarta: EKONISIA.

Mulyadi. 2015. Akuntansi Manajemen: Konsep, Manfaat \& Rekayasa. Jakarta: Salemba Empat.

Narbuko, Cholid dan Abu Achmadi. 2010. Metodologi Penelitian. Jakarta: Bumi Aksara.
Salman, Kautsar Riza dan Mochammad Farid. 2016. Akuntansi Manajemen Alat Pengukuran dan Pengambilan Keputusan Manajerial. Jakarta: Indeks.

Samryn, L.M. 2012. Akuntansi Manajemen Informasi Biaya untuk Mengendalikan Aktivitas Operasi \& Investasi. Jakarta: Kencana Prenada Media Group.

Simamora, Henry. 2012. Akuntansi Manajemen Edisi III. Riau: Star Gate Publisher.

Sodikin, Slamet Sugiri. 2015. Akuntansi Manajemen Sebuah Pengantar. Yogyakarta: UPP STIM YKPN.

Soeratno, dan Lincolin Arsyad. 2008. Metodologi Penelitian untuk Ekonomi dan Bisnis. Yogyakarta: UPP STIM YKPN.

Supardi. 2005. Metodologi Penelitian Ekonomi \& Bisnis. Yogyakarta: UII Press.

Siregar, Baldric, dkk. 2013. Akuntansi Manajemen. Jakarta: Salemba Empat. 